分析值 $\mathrm{Si} 11.63 \%, \mathrm{OH} \quad 9.31 \%$

$\mathrm{C}_{16} \mathrm{H}_{17} \mathrm{SiO}$ としての計算值 $\mathrm{Si} 11.59 \%, \mathrm{OH} \quad 7.02 \%$

収量 $7.5 \mathrm{~g}(76 \%)$

1.2.10 フェニルジ(n-プロピル)シラノール $(\mathbf{X})$ : さきに調製 した $n$ ープロピルグリニャール試薬を氷冷し, メチルトリクロル シラン $4 \mathrm{~g}$ を加光，以後は 】の場合と同様に処理して析出する粗 結晶を熱ベンゼン溶液から再結晶すれば $\mathrm{mp} 79^{\circ} \sim 81^{\circ} \mathrm{C}$ の白色 針状結晶を析出する。この結晶は $15 \%$ 水酸化ナトリウム水溶液 に透明に溶解し，ヶイ素および活性水素を含む。水に難溶である。

$$
\text { 分析值 } \mathrm{Si} 13.42 \%, \mathrm{OH} 7.23 \%
$$

$\mathrm{C}_{12} \mathrm{H}_{20} \mathrm{SiO}$ としての計算值 $\mathrm{Si} 13.48 \%, \mathrm{OH} \quad 8.16 \%$ 収量 $2.5 \mathrm{~g}(29 \%)$

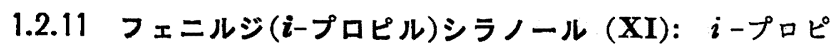
ルグリニャール試薬を用いるほかは，Xの場合とまったく同様に 処理して粗結晶をうる。熱ベンゼン溶液から再結晶すれば mp $93^{\circ} \sim 94^{\circ} \mathrm{C}$ の白色針状結晶をうる。この結晶はケイ素および活性
水素を含み，15\%水酸化ナトリウム水溶液に透明に溶解する。水 に難溶である。

分析值 $\mathrm{Si} 13.33 \%, \mathrm{OH} \quad 6.83 \%$

$\mathrm{C}_{12} \mathrm{H}_{20} \mathrm{SiO}$ としての計算值 $\mathrm{Si} 13.48 \%, \mathrm{OH} \quad 8.16 \%$ 収量 $1 \mathrm{~g}(11.6 \%)$

以上のようにしてえたシラノール類 $1 \mathrm{~g}$ を $100 \mathrm{cc}$ ビーカーに とり，アセトン $20 \mathrm{cc}$ に溶解し水 $5 \mathrm{cc}$ を加えてさらに濃塩酸を 混合すればしだいに白濁する。約 5 時間後に大量の水中に投入し エーテル $50 \mathrm{cc}$ で抽出すれば抽出液から無色透明の油状物質をう る。これらの物質は $15 \%$ 水酸化ナトリウム水溶液に不溶性であ り，ケイ素を含んでいるからシロキサンと考えられる。

本研究を行なうにあたり, 終始御鞭撻下さった本所福川貞臣研 究主任打よび活性水素定量に御助力下さいました北川睦夫氏に深 く感謝の意を表する。また研究試料を提供された信越化学工業株 式会社に厚く御礼申し上げる。

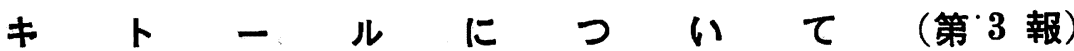

\section{光線によるビタミン $\mathbf{A}$ からキトールの生成}

(昭 和 35 年 5 月 27 日受理)

金子良 平†

光線によるビタミンAのキトール化について研究した。ビタミン $\mathrm{A}$ は遊離型でも，またエステル型でも光 2 量体であるキトール となるが,ビタミン Aの忣収する波長のうち, $300 \mathrm{~m} \mu$ より長波長域の光線が有効である。この反応に対し酸化防止剂はなんの効 果も示さず, $\beta$-カロチンのような色素はある程度の防止能を示すものと考えられた。また $300 \mathrm{~m} \mu$ より短波長の紫外線はビタる

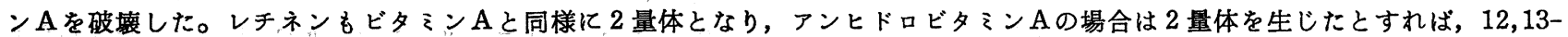
の位置で 2 量重合を起したものと考えねばならない。 $\beta$-カロチンは光に対して相当に安定であり，長時間の日光照射によっても 重合されにくいものと考えられた。またキトールの生体内での意義, その生成機構についても考察した。

さきにキトールの化学構造について研究し, キトールとビタる ン $\mathrm{A}$ と関連性をつぎのように結論した。キトールはビタミン $\mathrm{A}$ の 2 量体で熱分解によってビタミン Aを生成するという事実から, まずキトールをオゾン分解し,ゲロン酸 (II)を分離し,その収量か
Aの 2 倍の分子式を示し，8個の二重結合をむち，また $293 \mathrm{~m} \mu$ 付近にだけ吸収極大を示すキトールの諸性質を満足し得る。この ような二重結合によって 2 量体化されている化合物は天然物中に も見いだされ，その多くはシクロブタン環を形成して 2 量体化さ
ら $\beta$-ヨノン環が 2 個存在するこ とを確認した。つぎにキトールの セレン脱水素反応を行ない1,6-シ メチルナフタリン( 相)を分取し， ビタミン $\mathrm{A}$ と同様に $\mathrm{R}_{1}$ 基をるつ むのと考えた。またその吸収スペ クトルから検討し，その分子中に はビタミン $\mathrm{A}$ 鎖の 1 部である共役 テトラエン基 $\mathrm{R}_{2}$ を 2 個有するこ とを推定し，すなわちキトールは Iのようにビタミン A の $13,14-$ の二重結合によってその 2 分子が 結合したものではなかろうかと考 えた。このI 式とすればビタミン

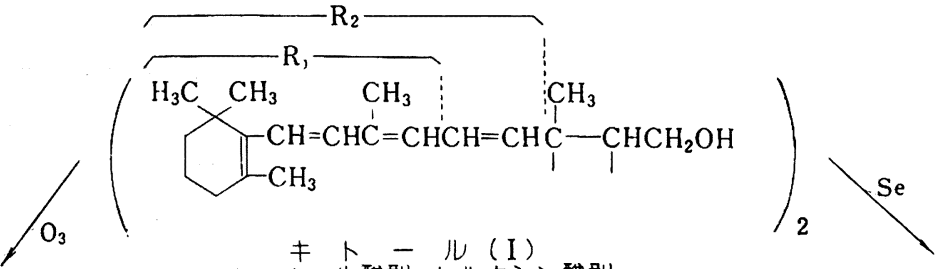<smiles>COC(=O)C(C)(C)CCCCC(C)(C)C</smiles>

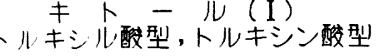

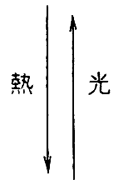<smiles>CC(C)(O)O</smiles><smiles>CC(C=CCO)=CC=CC(C)C=CC1CC2CCC(C)(C)C1C2</smiles>

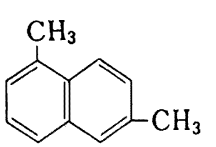

1,6-シメチルナフタリン

(III) 
れているものである。たとえばケイ皮酸とトルキシ ル酸（トルキシン酸）の関係であり,この 2 量体の トルキシル酸は加熱によりケイ皮酸となる。この事 実はキトールの熱分解によるビタミン $\mathrm{A}$ 生成と同 一の反応である。以上のようにキトールI はビタミ ンA 2 分子がその 13,14-の二重結合によってシク ロブタン環を形成し，2 量体化されているものとし た1。またケイ皮酸をトルキシル酸にする反応，す なわちシクロブタン環を形成して 2 量体となる反応 は，大体日光照射によって進行する。したがってビ タミンAを日光照射しキトールとなし得る可能性が 考えられた。一般にビタミンA は光により重合ある いは破壊されビタミン $\mathrm{A}$ 効力を失なうと考えられて いたが，著者は予期したように合成ビタミンAパル ミテートに日光を照射し，はじめてキトールを生成 することができ，速報として発表したが，同時にさ きのキトールの構造式 I をさらに確実なものとし た2)。そののち，表は本実験とは別個にキトールの 化学構造を研究し, 主として吸収スペクトルから類 推し構造式としてＩ のトルキシル酸型を推定し3),

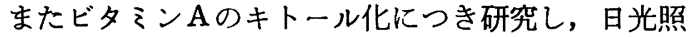
射, 加熱, 加熱急冷する方法, 空気酸化による方法, 化学試薬による 2 量体化など試みたが，ほとんどキ トール化が見られなかったと報告しているむ。

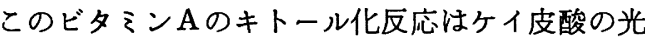
2 量体化反応*1 と同様にラジカル反応と考光られる が，本報にはその詳細を報告する。ビタミンAおよ びキトールの吸収スペクトルのうち $290 \mathrm{~m} \mu$ 付近の $E_{1 \mathrm{~cm}}^{1 \%}$ 值を表 1 に示したが，両吸収曲線は $290 \mathrm{~m} \mu$ 付近で交わり，等しい吸収をもつ波長，等吸収点を 示す。またキトールおよびビタミン $\mathrm{A}$ の混合物の吸 収スペクトルを計算する場合，その吸収スペクトル には加成性がなりたつものと考えてよいので，その 混合比にかかわらず必ずさきの等吸収点をとおる。

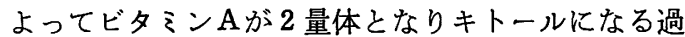
程を考えると，ビタミン $\mathrm{A}$ の吸収スペクトルは 290 $\mathrm{m} \mu$ に等吸収点を示しつつ，その吸収極大は吸光係 数の減少をともない徐々に短波長域に移動し，つい にキトールの吸収スペクトルと一致するものと考え られる。またエステル型の場合も $290 \mathrm{~m} \mu$ に等吸収 点を示す。実際にビタミンA（エステル型としてパ ルミテート2), 大鮫，たら，いしなぎなどの天然肝
(A)
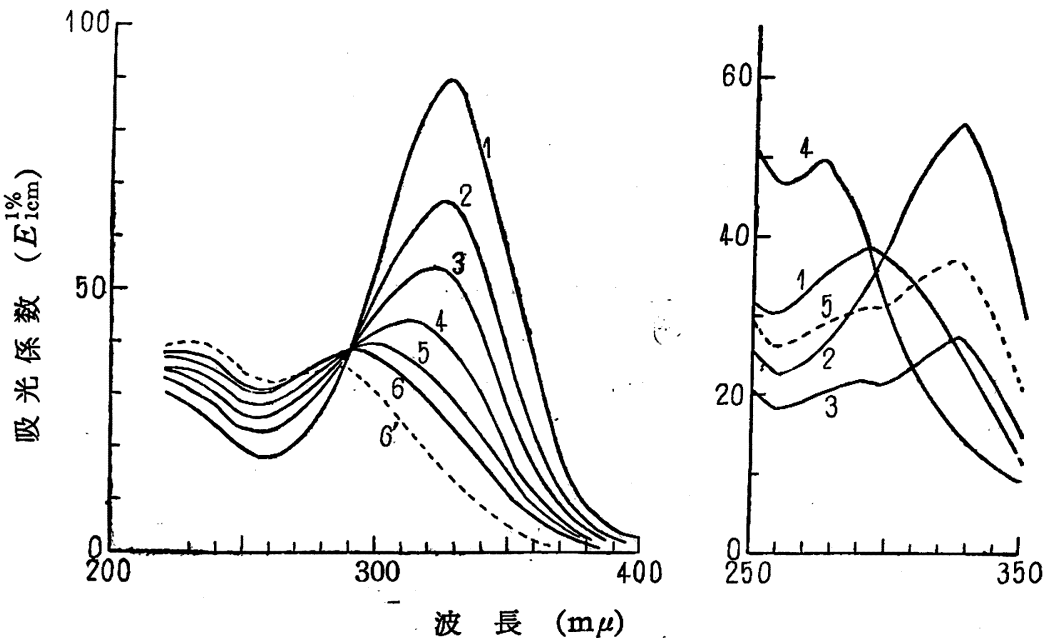

(A) 1：大鮫肝油，9 月12日， $n_{\mathrm{D}}^{20} 1.4857 ， 2 ： 5$ 日後， $n_{\mathrm{D}}^{20} 1,4840$, 3：10日後, $n_{\mathrm{D}}^{20} 1.4837,4: 20$ 日後, $n_{\mathrm{D}}^{20} 1.4835,5 ： 30$ 日後, $n_{\mathrm{D}}^{20} 1.4833,6 ： 40$ 日後, $n_{\mathrm{D}}^{20} 1.4831,6^{\prime}: 80$ 日後, $n_{\mathrm{D}}^{20} 1.4829$

(B) 1 : 日光硩射生成物 (A6) $(7.1 \mathrm{~g}), 2$ : 留分 I $\left(200^{\circ} \mathrm{C}, 3 \mathrm{~g}\right), 3$ : 留分 I $\left(220^{\circ} \mathrm{C}, 2.2 \mathrm{~g}\right), 4:$ 残留物 $(1.4 \mathrm{~g}), 5:(2,3,4$ 加ら の逆算)

圀 1 大鮫肝油の日光照射 (A) 打よび生成物の分子蒸留 (B)
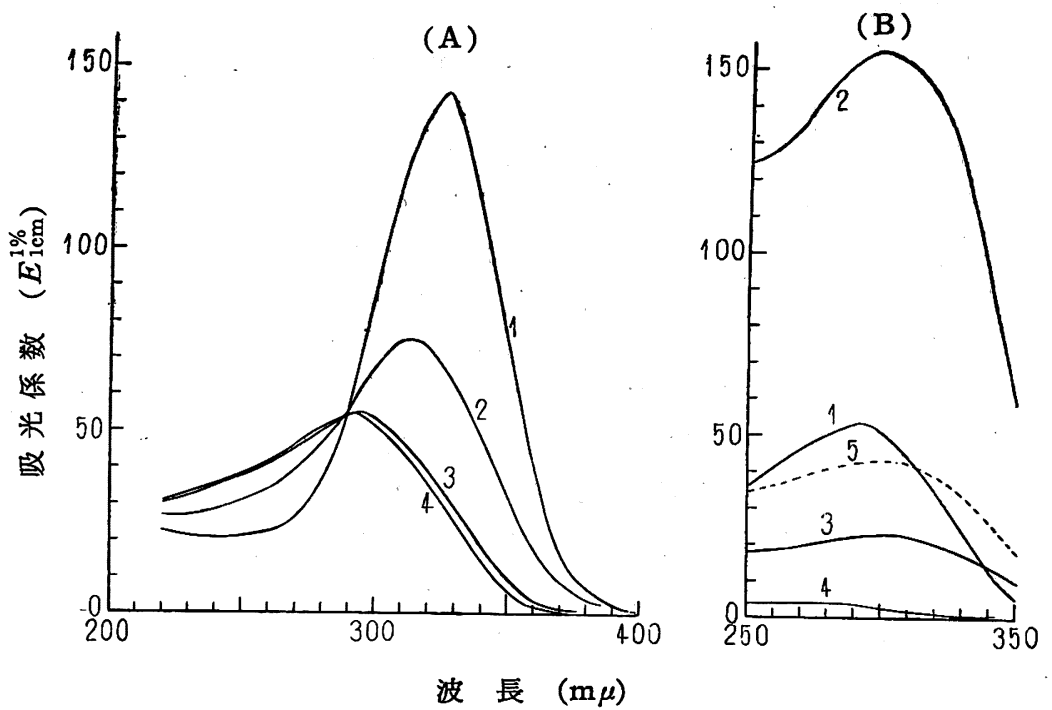

(A) 1：ビタミンAアセテート，6月19日，2：5日後，3：10日後， 4: 12 日後

(B) 1：日光照射生成物 (A4) $(7.7 \mathrm{~g}) ， 2$ ：留分 I $\left(170^{\circ} \mathrm{C}, 1.7 \mathrm{~g}\right)$, 3 ：留分 II $\left(190^{\circ} \mathrm{C}, 1.6 \mathrm{~g}\right), 4:$ 残留物 $(4.0 \mathrm{~g}), 5:(2,3,4$ からの逆算)

図 2 ビタミンAアセテートの日光照射 (A) および生成物の分子蒸留 (B)

表 $1290 \mathrm{~m} \mu$ 付近のビタミンA $\mathrm{A}$ およびキトールの $E_{1 \mathrm{~cm}}^{1 \%}$ 值 (イソプロパノール)

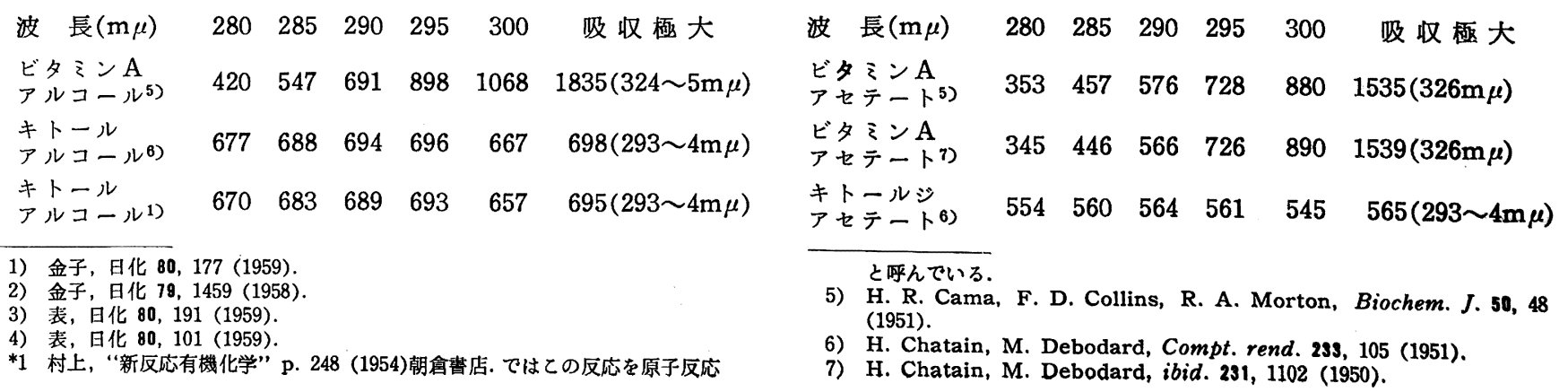


油，アセテート，および遊離型ビタミンA油）に日 光を照射し，その吸収スペクトルを測定していくと， たとえば図 1 〜図 3 に示したように，さきの理論的 な考え方と同様にビタミン A の吸収極大は吸光係 数の減少をともない徐々に短波長域に移り, 最後に $293 \mathrm{~m} \mu$ 付近にいたり大体反応は終結する。その生 成物の吸収スペクトルはキトールの吸収スペクト ル136)とよく類似し，またこの反応中 $290 \mathrm{~m} \mu$ に等 吸収点を示した。また後に述べるようにビタミンA アセテートを日光照射した場合，生成物の分子量は 約 2 倍となった。よって日光照射によりビタるン A は2 量体化しキトールとなると考えてよい。またこ の反応中, 試料の屈折率は徐々に減少するが; これ は二重結合の消失に原因するものである。これらの 日光照射生成物は第 2 報2)に述べたように熱分解に よって，その吸収極大は長波長域に移動し，キトー ルの場合と同様にビタミン $\mathrm{A}$ 生成を示す。これら の生成物は逆転式分子蒸留器によって $10^{-4} \mathrm{mmHg}$ で分子蒸留したが，ビタミンAパルミテート2，天 然ビタミンA油すなわち長鎖脂肪酸エステル(図 1 ) の場合, すべてビタミン $\mathbf{A}$ (エステル) を生成留出 した。またこの場合のビタミン $\mathrm{A}$ の生成率はその構 造式 I からもわかるように, 理論的には $2 \mathrm{~mol}$ のビ タミンAを生成するはずであり，表 1 からわかるよ らに熱分解物のビタミン $\mathrm{A}$ の吸収極大における全吸 収はキトール化合物の $293 \mathrm{~m} \mu$ における吸光係数の 約 2.7 倍になるはずであるが，この解 2 量体化反 応は条件そのむのがかこくすぎて, 収量は多くの文 献8)8 16)のように $1 \mathrm{~mol}$ 以下と考えられた。また 遊離型のキトールの場合, 分子蒸留によりその吸収 極大が少し長波長域に移動した程度のものしか得ら れず(図 3), 石川ら 10)る指摘しているようにキトー ルは少量にはビタミン $\mathrm{A}$ 化が行なわれるが，大部分 はそのまま留出されるものと考えられる。キトール ジャテートも分子蒸留により僅少しかビタミン $\mathbf{A}$ 化が行なわれず，そのまま留出された(図 2 )。これ らの事実から分子蒸留によるキトールのビタミン $\mathrm{A}$ 化はキトールの遊離型，エステル型の別ではなく， キトール化合物（エステル）がそのままでは蒸留さ れにくいような大きさの分子量の場合，シクロブタ ン環での解 2 量体化が起き,ビタミンAエステルと なり蒸留されるむのと考えられる。

以上のキトール化反応は空気と遮断して行なっているが, 油脂 中の溶存酸素が影響をおよぼすかどうかしらべるため, 遊離型ビ タミン $\mathrm{A} の 2$ 量体化の際, 酸化防止俞（BHT）*2 を加えたもの

8) N. D. Embree, E. M. Shantz, J. Am. Chem. Soc. 65, 910 (1943)

9) F. B. Clough, H. M. Kascher, C. D. Robeson, J. G. Baxter, Science 105, 436 (1947).

10）石川, 表, 鬼島, 奥田, Sci. Rep. Whales Research Institute No. 5 , 61 (1951).

11) 阿河, 小森, 西村, 油脂化㙝 1, 12 (1952)

12) 表, 日化 80, 97 (1959).

13) S. A. Burnasheva, I. E. Gekker, V. I. Mukhina, Ryibno Khazyaistvo ${ }^{*}(1), 67$ (1958); 真空化学 6, 123 (1958).

14）表, 其空化学 7, 106 (1959).

*2 Butylated hydroxytoluene
(A)

(B)
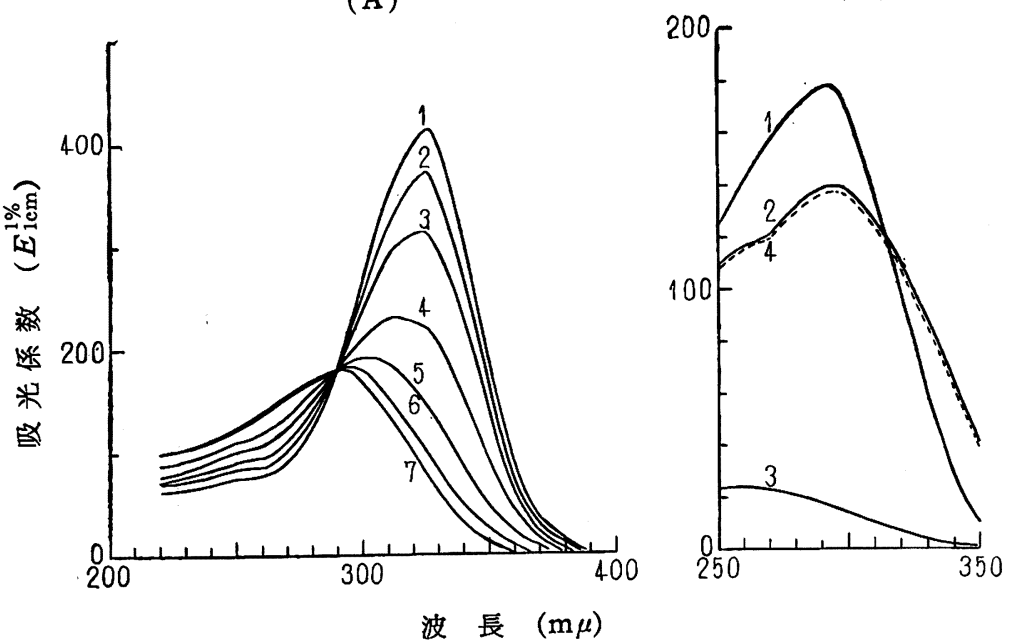

(A) 1: ビタミンAアルコール, 11 月 7 日， $n_{\mathrm{D}}^{20} 1.5134,2: 5$ 日後, $n$ D 1.5112，3：10日後， $n_{\mathrm{D}}^{20} 1.5090 ， 4: 20$ 日後， $n_{\mathrm{D}}^{20} 1.5058$, 5: 30 日後, $n_{\mathrm{D}}^{20} 1.5034,6: 45$ 日後, $n_{\mathrm{D}}^{20} 1.5019,7: 65$ 日後, $n \underset{\mathrm{D}}{20} 1.5015$

(B) 1：日光照射生成物 $(\mathrm{A} 7)(4.7 \mathrm{~g}), 2$ ：留分 I $\left(220^{\circ} \mathrm{C}, 4.2 \mathrm{~g}\right)$, $3:$ 残留物 $(0.1 \mathrm{~g}), 4:(2,3$ 加らの逆算 $)$

図 3 ビタミンAァルコールの日光照射 (A) および生成物の分子弥留（B）
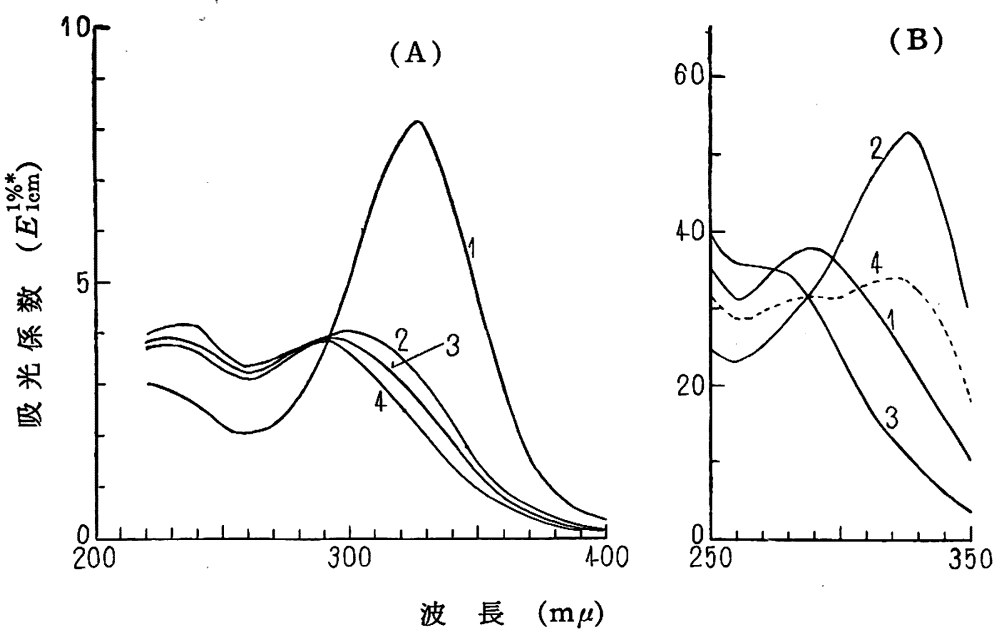

(A) 1：大鮫肝油ヘプタン溶液，3月11日，2：5 日後，3：7 日後, 4：9日後，*試料溶液の vol \%として算出した.

（B） 1：日光照射生成物 (A4 の溶剤を除去したもの) $(12 \mathrm{~g}) ， 2$ ：留分 I $\left(210^{\circ} \mathrm{C}, 6.3 \mathrm{~g}\right), 3:$ 残留物 $(5.1 \mathrm{~g}), 4:(2,3$ 加らの逆算 $)$

図 4 大鲛肝油ヘプタン溶液の日光照射 (A) 扣よび生成物の分子蒸留 (B)

と対照的に試験したが，なんら変わるところなくまったく同一速 度でキトール化が進み, 酸化防止剤はこのラジカル反応には防止 効果を示さなかった。

またこのキトール化反応完了後，さらに長時間日光照射すると 図1のように吸収曲線は等吸収点をはずれ，その吸収極大は短波 長部 $(285 \mathrm{~m} \mu$ 付近) に移動したが，その構造式 I からもわかると おりシクロブタン環に対する異性体があるはずであり，その異性 化反応が行なわれるものと考えられ，このものも分子蒸留により ビタミンAを生成した。日光によって 2 量体以上に重合するとは 考えられない。天然のキトールでも，その分離法によっては 293 $\mathrm{m} \mu$ 以下に吸収極大を示すものが得られる1)が，このことを裏づ 
ける事実と思う。

以上の実験は油脂に溶解したビタミン Aのキトール化であるが，他の有機溶剂 中での 2 量体化についても実験した。す なわちへプタン，イソプロパノール溶液 としたビタミン A に日光を照射したが図 4 に示したように油脂中の場合と同様に キトールとなった。表いはビタミン $\mathrm{A}$ 濃 縮物の石油エーテルおよびイソプロパノ 一ル溶液に日光照射しキトール化を試み たもののキトールの生成を認められなか ったと報告しているが，照射が長時間す ぎ酸化重合などが主となったのではない かと考えられる。

つぎにこのラジカル反応を促進する光 線の波長について検討した。ビタミン $\mathrm{A}$ は紫外線照射により黄色の螢光 ${ }^{15)}$ 発 し，破壊されるものとされ，この方法に

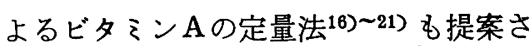
れている。太陽光線は $390 \mathrm{~m} \mu$ 付近に最 強のエネルギーをもち, 紫外部から可視, 赤外部にわたる光線を地球上に到達させ ているが，この日光にほぼ近い光線とし て使用されている炭素アーク燈もビタミ ンAを定量的にキトールとした。ついで 水銀燈を用い，ビタミンAに対する紫外 線の作用をしらべた。水銀スペクトルの うち, 強力で光化学に利用し得る 線は 5791, 5770; 5461; 4358; 4047; 3663, 3654,$3650 ; 3341,3132,3126 ; 3021$,

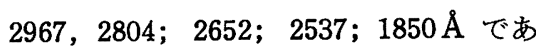
るとされている22)が，ビタミンA油を石 英容器に密封し，水銀燈を照射したとこ ろ図 5 に示したようにビタミンAの吸収 スペクトルは，さきの日光によるキトー ル化の場合とはまったく反し，290 $\mathrm{m} \mu$ に等吸収点を示さず，全体に減少しなが ら,わずかに 280〜285 m $\mu$ に吸収帯を 示すものとなった。この生成物を分子蒸留すると，わずかにビタ ミン $\mathrm{A} の$ 生成がみられ，また熱分解後の吸収スペクトルは熱分解 前の吸収スペクトルより少し増大しているが，これは油脂の熱に よる異性化などによるものと考劣られる。よってこの吸収帯はキ トールのみによるものとは考えられず，紫外線によりビタミン $\mathbf{A}$ は大体交献に示されるように，単に重合あるいは破壊されるもの と考えられる。

15）八木, 吉田, 太幡, “螢光” p. 121, 203, 348 (1958) 南江.堂.

16) R. W. Little, Ind. Eng. Chem., Anal. Ed. 16, 288 (1944).

17) O. A. Bessey, O. H. Lowry, M. J. Brock, J. A. Lopez, J. Biol. Chem. 166, 177 (1946).

18) J. G. Bieri, M. O. Schultze, Arch. Biochem. \& Biophys. 34, 273 (1951).

19）佐橋，斎藤，吉田，中山，宮崎，原島，ビタミン 8, 589 (1953)

20）藤田, “ビタミン定量法” p. 115, 174 (1955) 南江堂.

21) 木村, ビタミン 11, 362 (1956).

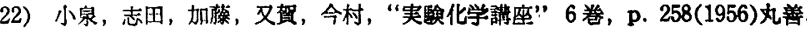

(A)

(B)
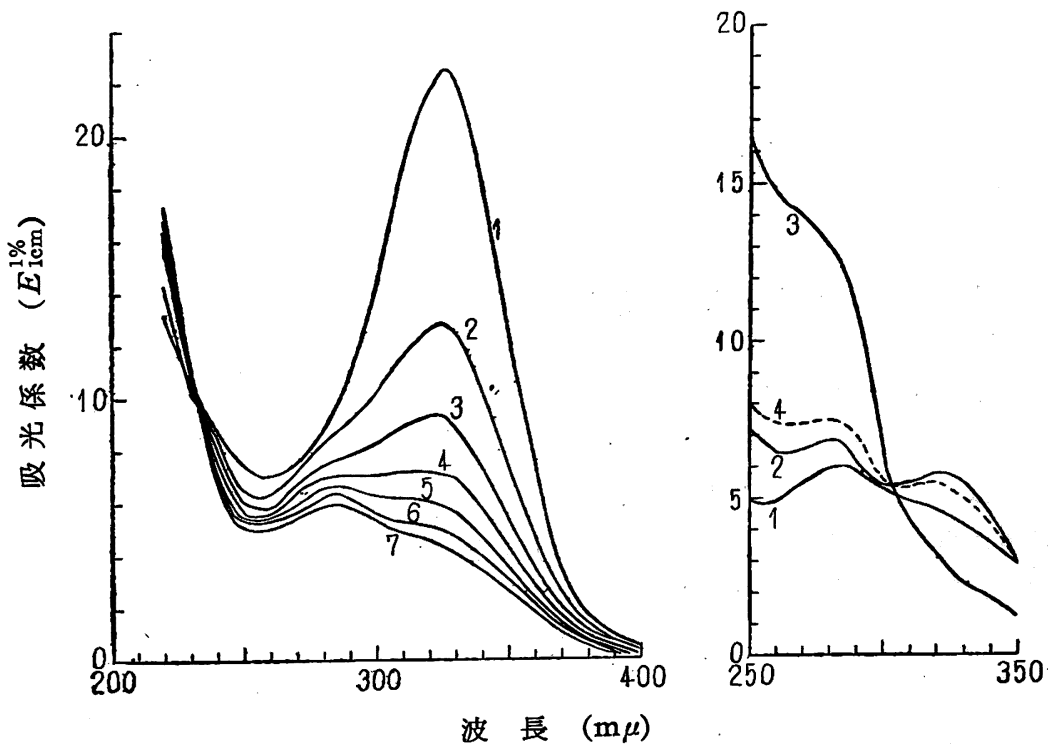

(A) 1: ピタミンA油, 2: 100 時間後, 3:200 時間後, 4:300 時間後, 5: 400 時間後, $6: 500$ 時間後, $7: 600$ 時間後

1：紫外線照射生成物 $(\mathrm{A} 7)(4.3 \mathrm{~g}), 2$ ：留分 I $\left(220^{\circ} \mathrm{C}, 3.3 \mathrm{~g}\right) ， 3$ ：残 留物 $(0.4 \mathrm{~g}), 4:(2,3$ からの逆算 $)$

図 5 ピタミンA油の紫外線照射（A）扎よび生成物の分子蒸留（B）

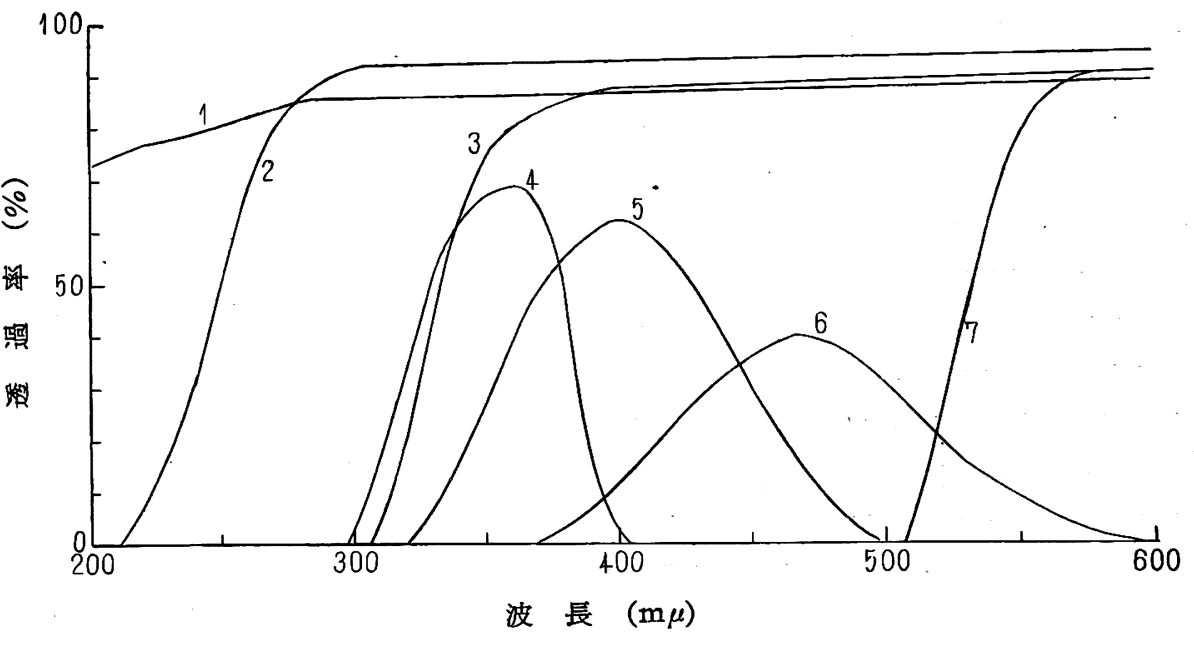

1: シリカセル, 2: UV-25, 3：ガラス容器, 4: UV-D2, 5: V-V2, 6: V-B2A, 7: V-03A

図 6 実験容器打よびフィルターの透過率

またこの場合，ガラス容器を用いるとビタミンAは 2 量体化 しキトールとなったが，このガラスの透過率は図 6 に示したよう に $300 \mathrm{~m} \mu$ 以上の光線を透過するので, さきの石英の容器で行な った場合から考察し，大体 $300 \mathrm{~m} \mu$ 付近から短波長の紫外線はビ

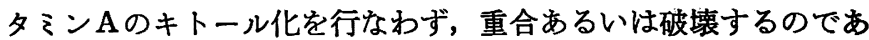
ろうと考えられた。この紫外線のうち，ビタミン $\mathrm{A}$ の個々の二重 結合に作用をおよぼすと考えられる $1850 \AA$ の光線を除くため, UV-25 フィルター（図 6 ）を使用して実験したが，紫外線を直

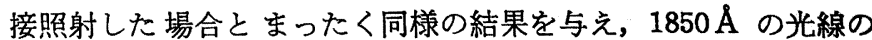
影響だけではなく，大体 $300 \mathrm{~m} \mu$ 以下の短波長の紫外線はビタミ ンAをキトール化せず,重合あるいは破壊するものと考えられた。 $300 \mathrm{~m} \mu$ より長波長の光線がキトール化に有効と考えられるので 二,三のフィルター（図6）を使用してこの反応を検討した。 U V-D2 を使用した場合，多少ビタミンAの破壊をともなうよ 
うに考えられたが，キトール化が行なわれ，ま たそれより長波長に透過光を示す V-V 2 でも すみやかに反応が遂行された。つぎに可視部に 透過光を示すV-B2Aを使用したが，その場合 反応速度はにぶったがキトールを生成した。つ いで可視線の $500 \mathrm{~m} \mu$ 付近より長波長の光線を 透過する V-03A を用いた場合, はじめはわず かにキトール化が行なわれるように思われた が, その後反応はまったく停止した。とのビタ ミンAのキトール化反忘は大体 $300 \mathrm{~m} \mu$ 付近か ら $400 \mathrm{~m} \mu$ ぐらいの光線为より効果的に㗢き, それより長波長の光線になるにしたがい弱くな るように考元られる。この効果的に 2 量体化反 応を行なら光線の波長域はビタミン $\mathrm{A}$ の吸收帯 に重なり,当然のことながらグロットゥスードレ イパーの法則にしたがい，ビタミンAがこの光 線を吸収して励起されキトール化するのである ら゙。ま $300 \mathrm{~m} \mu$ より短波長の紫外線はエネルギ 一的につよすぎ, ビタミンAの共役二重結合系 を破壊あるい恃重合させるのであろうと思う。 以上述ベたキトール化の逆反応である解 2 量体 化反応法, 紫外線部から可視光域の光線ではま ったく認められず，キトールは熱エネルギーに よってのみビタミンAを再成する。このことは ケイ皮酸, スチルベン, ベンシシリデンアセトン などの光 2 量体は紫外線によって単量体を再成 する28)という現象とまったく異なっている。

またこのビタ ミン Aの光 2 量体化反応は一般 的に色相の濃いむのは反応がおそく, 淡色なむ のはすみやかにキトール化したが，これは肝油 中の天然色素が光を吸収し 2 量体化を防止して いるむのと考えられる。よって淡色なビタミン A 油に $\beta$-カロチンを添加し, 実験を行なった ところ， $\beta$-カロチンはある程度の防止能をむつ ことを知った。

この光 2 量体化反応はビタミンAの同族体に ついても起るかどうか実験を行なった。まずレ チネン（ビタミンAアルデヒド）を日光照射し た場合, 図 7 亿示すように明らかな等吸収点は 示さずレチネンの $383 \mathrm{~m} \mu$ の吸収極大は徐々に 減少し短波長域に移動し，293 $\mathrm{m} \mu$ 付近に吸収 極大を示すむのとなった。ての反応中，ビタミンAの場合と同様 に屈折率は隇少した。また照射中，不溶性の沈殿の生成が認めら れたが，これはカルボニル基による副反応と考えられ，このよう なため等吸収点を示さないのかもしれない。かりにレチネンがビ タミンA と同様に 13,14-の二重結合によって 2 量体化されたと すれば，その 2 量体はキトールと類似の波長に吸收極大を示すむ のと考えられる。ついでこれを分子蒸留したところ，留出物は照 射物より長波長部 $370 \mathrm{~m} \mu$ 付近に吸収極大を示し, キトールア ルコールの場合と同様に完全には単量体とはならないが, レチネ ンを再成したと考光て差支えない。つぎにビタミンAの脱水物で 23) A. Mustafa, Chem. Rev. 51, 1 (1952).
(A)

(B)
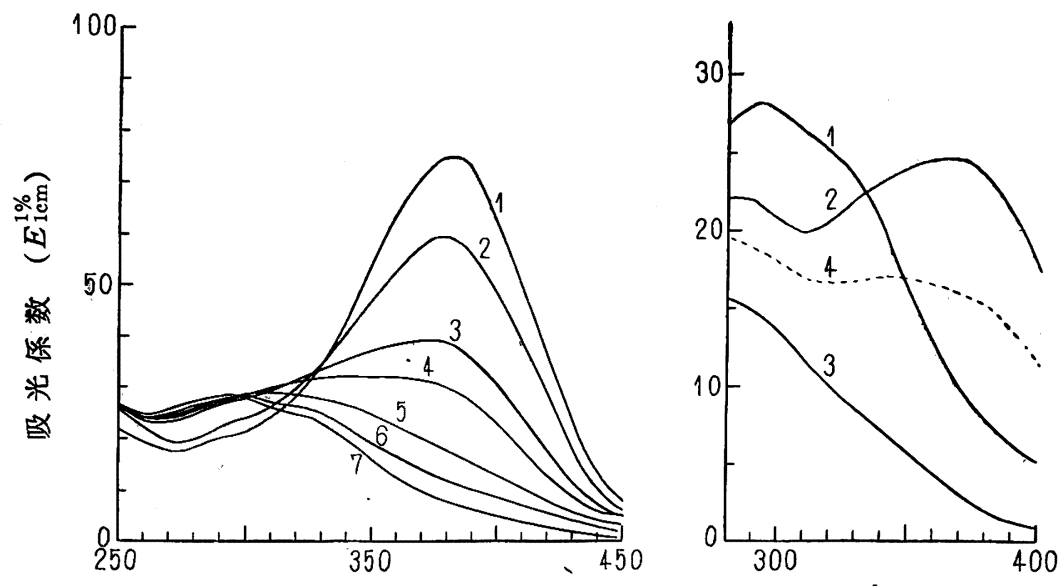

波 長 $(\mathrm{m} \mu)$

(A) 1：レチネン，9月12日， $n_{\mathrm{D}}^{20} 1.4902 ， 2 ： 5$ 日後， $n_{\mathrm{D}}^{\text {\%0 }} 1.4882$, $3 ： 15$ 日後, $n_{\mathrm{D}}^{90} 1.4870,4: 25$ 日後, $n_{\mathrm{D}}^{0} 1.4858,5: 37$ 日後, $n_{\mathrm{D}}^{20} 1.4848,6$ ：50日後, $n_{\mathrm{D}}^{90} 1.4840,7: 65$ 日後, $n_{\mathrm{D}}^{30} 1.4837$

(B) 1: 日光照射生成物 $(\mathrm{A} 7)\left((7.0 \mathrm{~g}), 2\right.$ : 留分 I $\left(210^{\circ} \mathrm{C}, 4.0 \mathrm{~g}\right)$, $3:$ 残留物 $(2.5 \mathrm{~g}), 4:(2,3$ 加らの逆算 $)$

因 7 レチネンの日光照射 (A) および生成物の分子苲留 (B)
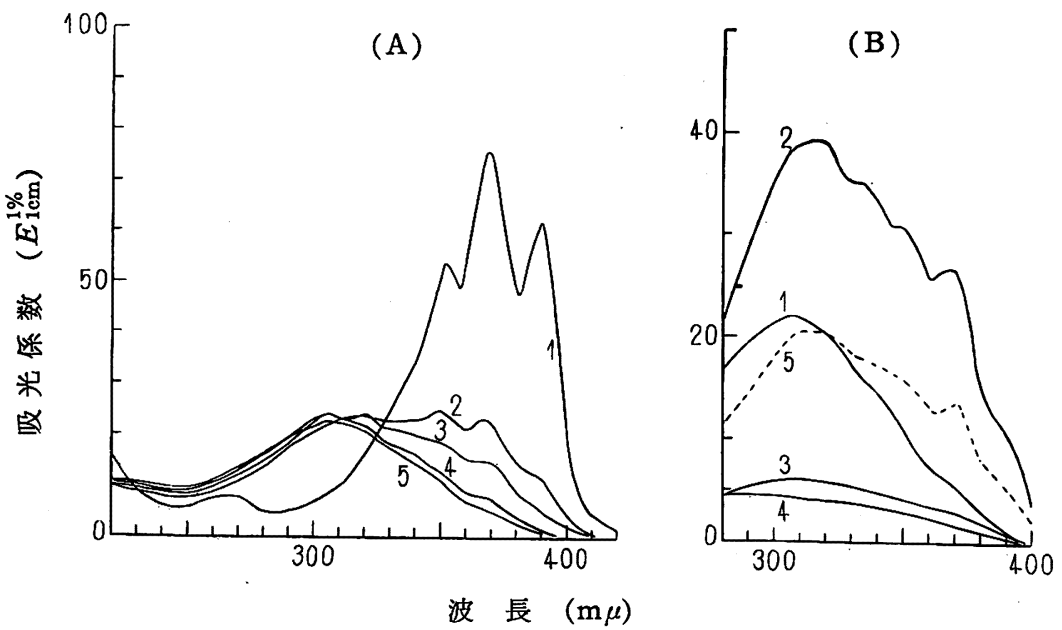

(A) 1：アンヒドロビタミンA，9月27日， $n_{\mathrm{D}}^{20} 1.4850 ， 2 ： 5$ 日後, $n_{\mathrm{D}}^{20} 1.4822,3 ： 10$ 日後, $n_{\mathrm{D}}^{20} 1.4811 ， 4: 15$ 日後, $n_{\mathrm{D}}^{20} 1.4805$, 5 ：20日後, $n_{\mathrm{D}}^{20} 1.4804$

(B) 1：日光照射生成物 $(\mathrm{A} 5)(7.4 \mathrm{~g}), 2$ : 留分 I $\left(200^{\circ} \mathrm{C}, 3 \mathrm{~g}\right), 3$ : 留分 $\mathbb{I}\left(230^{\circ} \mathrm{C}, 3.2 \mathrm{~g}\right), 4:$ 残留物 $(0.6 \mathrm{~g}), 5:(2,3,4$ 加 万 の逆算)

図 8 アンヒドロビタ ミン Aの日光照射 (A) 扰よび生成物の分子蒸留 (B)

あるアンヒドロビタミンAに日光照射したところ(図 8)，光に対 し不安定で,すみやかにその吸収スペクトルは变化し,最後に 305 $\mathrm{m} \mu$ 付近に吸収極大を示すむのとなった。この場合, ビタミン $\mathrm{A}$ と同㥞に二重結合によって 2 量体化したとするならば，末端の 14,15-の二重結合の位置で行なわれると共役ペンタエンが残り, 生成物の吸収極大が合わず(計算值 $\left.\left.{ }^{24}\right) 334.8 \mathrm{~m} \mu\right), 12,13$-の位置で 2 量体化している（計算值 ${ }^{24} 295.5 \mathrm{~m} \mu$ ) と考光た方がよい。ま たこの生成物を分子蒸留すると，この物質は $200^{\circ} \mathrm{C}$ 付近で留出 し，長波長側にアンヒドロビタミン A の生成を想起させるような 吸收帯を示し，キトールがアルコール型の場合ビタミン A 熱分

24) 平山，日化 75，29，667，674:(1954). 


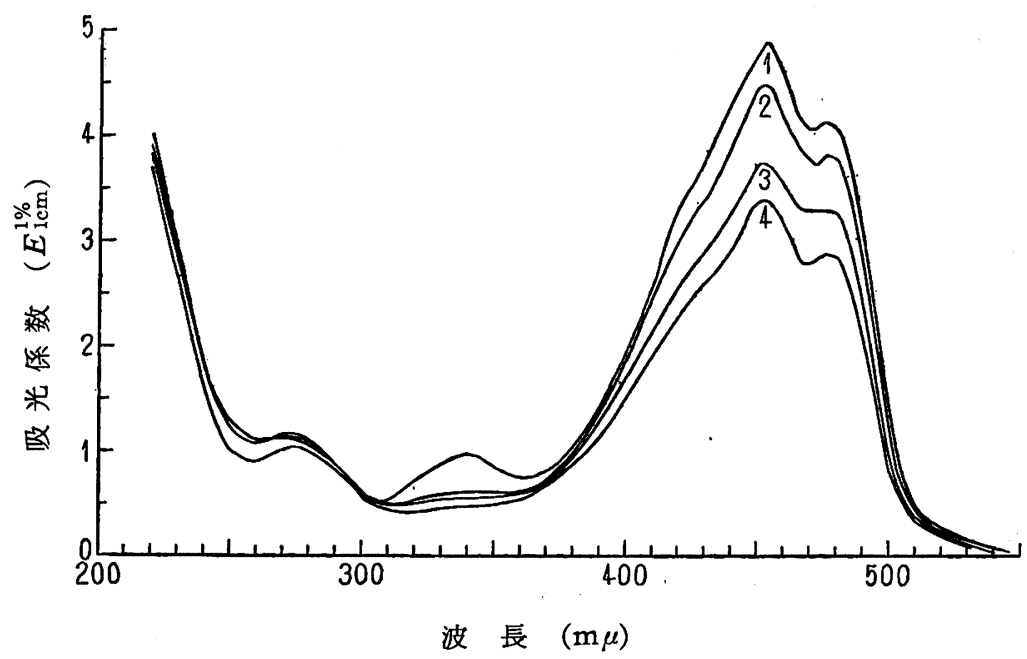

1: $\beta$-カロチン, 6 月 23 日, 2: 20 日後, 3:70日後, 4:130 日後

図 $9 \beta$-カロチンの日光照射

解されず，そのまま留出するのと同様に考光られる。

プロビタミンAである $\beta$-カロチンは日光により立体異性化を 起す25226)ことはよく知られており，また木村21は $\beta$ ーカロチンの $1 \mathrm{~N}$ 水酸化カリウム $90 \%$ エタノール溶液に紫外線を照射すると ビタミンAの場合と同様に破壊されると述べている。本実験では $\beta$-カロチンを油脂に溶解し日光照射したが（図 9), その吸収帯 は日光に対し割合安定であり, $340 \mathrm{~m} \mu$ 付近のシス-極大 $\left.{ }^{25}\right) 26$ )は消 失したが，長時日照射しても可視光域の吸収帯は徐々に減少する のみで，他の短波長域に 新らしい吸収帯の出現は見られず， $\beta$ -

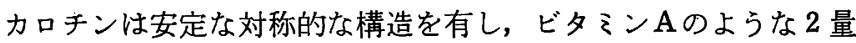
体化反応は起さないものと考兄られた。

なおキトールの生体内での意義および生成について考察した。

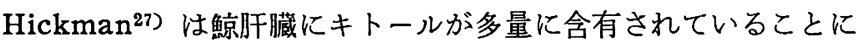
関しつぎのように述べている。一般に魚類は哺乳動物よりビタる ンAを多量に要求し，またそれに堪え得るむのと考えられ，鲸の ような哺乳動物が海産の食餌だけに制限され，過剩のビタミン A を摄取するのでその過剩症による毒性を除くため, 不活性のキト 一ルとし，体内に保存するもので，プロビタミンというよりもむ しろポストビタミンと云うべきであろうとした。しかし Deue128) はとれほど多量のビタミンAをとらないと考えられる牡牛や羊う 肝油中にキトールが見いだされ，またラットに過剩のビタミン $\mathrm{A}$ を与えてもキトールをつくらない*3こと，またビタるンAの毒性 に比較的免疫性があると見なされる鮫のような魚類にもキトール が存在しているとし，Hickman の説をそのまま擁護するわけに はいかないと述べている。しかしながら一般に水棲，陸棲を問わ ず動物のビタミン $\mathrm{A}$ 保有量はその種類，生活環境，その老若など によって異なり，これらによって大体の必要量ないし許容量があ るものと思われ，それより過剩になった場合に不活性のキトール となすと考元れば,ビタミン $\mathrm{A}$ 含量の比較的少ない牡牛, 羊の肝臟 にキトールが含有されていても不思議はないと思う。また著者の

25) L. Zechmeister, "Vitamins and Hormones" Vol. VII, p. 57 (1949) Academic Press Inc. Publ., New York.

26) 㚼, 化学の領域 2, 148 (1948).

27) K. Hickman, Ann. Rev. Biochem. 12, 353 (1943).

28) H. J. Deuel, "The Lipids" Vol. I, p. 710 (1951) Interscience Publ., New York.

*3 E. M. Shantz 加 H. J. Deuel への私伊 (1948)
調べたところによると，ビタるンAを含む魚類の肝 油中には少量ながらほとんどキトールが共存してい た299。またラットがキトールを生成できないという が，はっきりした交献はなく、令後の研究にまつほ かはない。キトールの生体内生成について, 表33) はビタミン $\mathrm{A} の 2$ 量体化は不成功であったとし; ビ タミン $A_{1}$ を化学的に $A_{2}$ にする場合, ビタミン $A_{1}$ 酸またはアルデヒドを脱水素して $\mathrm{A}_{2}$ 体にできるこ と，また光 2 量体化の場合，たとえばジベンザルア セトンのように，その二重結合がカルボニル基によ り活性化されるためであろうと述べ，キトールの場 合もこれと同じょうにビタミンAがアルデヒドとな り,これが 2 量体化し，さらに還元されてキトールに なるのであろうと考えられた。しかしながらさきに 述べたように,ビタミンA は遊離型でもエステル型 でもほぼ定量的にキトールとなり，レチネンの場合 は不安定で 2 量体化するとしてる収量は覀い。レチ ネンは眼網膜でタンパク質と結合したロドプシンとして存在し， ロドプシンは光線によりレチネンとオプシンとに分解され， ロ ドプシンはレチネンあるいはビタミン $\mathrm{A}$ とオプシンからつくられ る30)という。体内ではレチネンはビタミンAにくらべその量も少 なく, この光化学反応において，その副反応としてレチネンが 2 量体化するとは思われず，さきに述べたように生体内では過剩の ビタミンAがなんらかの酵素のような作用によりキトール化する ものであろうと考えられる。

\section{1 実 験 の 部}

\section{1 日光による天然ビタミン $\mathbf{A}$ 油のキトール化およびその分}

\section{子蒸留}

この実験に用いたガラスビンは内径 $2 \mathrm{~cm}$, 容量 $8 \mathrm{cc}$ のもの で，そのガラスの透過率は図 6 に示したが，以後の実験において もとくにととわらないかぎり本容器を用いた。また吸収スペクト ルの測定にはイソプロパノールを用いた。

大鮫肝油 $8 \mathrm{cc}$ をこのガラスビンに入れ，空気を窒素で置換し 密セン，封ロウし日光照射した。この試料を定期的にとり，その 吸収スペクトルおよび屈折率を測定したが，その結果は図 1 に示 した。また得られたキトール化物の Carr-Price 反応は青紫色か ら暗赤色となった。つぎにこのキトール化物を $10^{-4} \mathrm{mmHg}$ で逆 転式分子蒸留器を用いて蒸留するとビタミン $\mathrm{A}$ を生成した。

たらっをぐろ,いしなぎ肝油などについても実験を行なったが， いしなぎ肝油の場合, $290 \mathrm{~m} \mu$ 认完全な等吸収点を示さなかった が，やはりキトールを生成した。

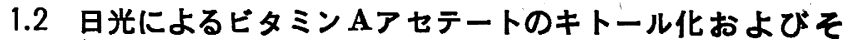
の分子蒸留

結晶ビタミンAアセテート（理研ビタミン製，1.4.2 参照）を 椿油に溶解し，この試料を日光照射してキトール化し，またその 分子蒸留を行なった（図 2 )。

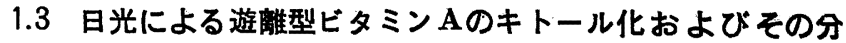
子蒸留, ならびに酸化防止郕添加の影響

分子蒸留したビタミン $\mathrm{A}$ 濃縮油を常法によりヶン化し，不ヶン

29）金子, 日本化学会第 13 年会講演 $(1960)$.

30) T. Moore, "Vitamin A" p. 263 (1957) Elsevier Publ. Co. 
化物としてビタミンAアルコールを分離し，これを椿油に溶解し て試料とした。実験結果は図 3 に示したが，これと比較のため試 料にBHT 1\%を添加し，同時にキトール化を行なったところ， 無添加の場合となんらかわることなくまったく同様な速度でキト ール化した。

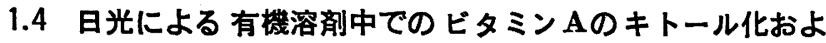
びその分子蒸留，ならびに分子量変化

1.4.1: 1.1 の試料大鮫肝油を $n$-ヘプタンの $10 \%$ 溶液となし， $500 \mathrm{cc}$ の共セン細口ビンに密封し，日光照射を行なった。その吸 収スペクトルの測定は，その一定容量をとり，これを $n$-ヘプタ ンで希釈して行なった。つぎに生成物は $n$-ヘプタンを減圧下に 蒸留除去し，分子蒸留してビタミン $\mathrm{A}$ 再成することを認めた （図 4 ）。また同時にイソプロパノール溶液（10\%）でのキトール 化も行なったが， $n$-ヘプタンの場合より長時日を要し, 約 25 日 間かかった。

1.4.2: $\mathrm{mp} 57^{\circ} \sim 57.5^{\circ} \mathrm{C}, E_{1 \mathrm{~cm}}^{1 \%}(326 \mathrm{~m} \mu)=1535$, 分子量 321.2 $\left(\mathrm{C}_{22} \mathrm{H}_{32} \mathrm{O}_{2}\right.$ としての計算值 328.5) の結晶ビタミンAアセテート $2 \mathrm{~g}$ を容量 $15 \mathrm{cc}$ のガラスビンに入れ，n-ヘプタンを加えて溶 解し密封して日光照射した。13日後,試料はキトール化したので, この溶液を減瓜下に溶剤を蒸留除去し，キトールジアセテートに 相当するむのを得た。このものは 288〜 $290 \mathrm{~m} \mu$ に吸収極大を示 し, $E_{1 \mathrm{~cm}}^{1 \%}$ は 518 [交献值 $\left.\left.{ }^{6}\right) E_{1 \mathrm{~cm}}^{1 \%}(293 \mathrm{~m} \mu)=565\right]$ であり，流動 乙難いあめ状物質であった。その分子量は 628 (水点降下法)を 示した $\left(\mathrm{C}_{44} \mathrm{H}_{64} \mathrm{O}_{4}\right.$ としての計算值 656.9$)$ 。

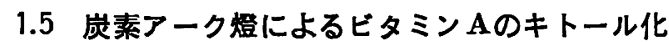

1.1 の試料大鮫肝油に, 退色試験機（アトラス社製）中で炭素 アーク燈を照射したところ，日光照射の場合と同様にキトールと なった（所要時間約 45 時間)。

1.6 ビタミン $\mathbf{A}$ に対する 紫外線の 作用ならびにキトール化反

\section{応を促進する光線の検討}

光源としてはマツダ光化学反応用水銀ランプ H L-400-P（石 英製）を使用し，試料は光源から約 $5 \mathrm{~cm}$ の位置に置き送風し冷 却しながら照射した。

1.6.1: 試料ビタミン A 油を紫外線吸収スペクトル測定用の 1 $\mathrm{cm}$ セル（透過率図 6) に密封し，紫外線を照射した。その吸収 スペクトルの変化および生成物の分子蒸留結果を図 5 に示した。

1.6.2: マツダ色ガラスフィルターUV-25（透過率図 6 ）を密 着した暗箱中に, 試料を入れた石英セルを置き, 光線をあてたと ころ, 1.6.1 と同様な吸収スペクトルの変化を起し, ビタミン $\mathrm{A}$ は破壊された。

1.6.3: 1.1 のガラスビンに試料を入れ密封し, 紫外線を照射し たところ， $290 \mathrm{~m} \mu$ の等吸収点は多少ずれるようであったがキト 一ル化した（所要時間約 250 時間）。

1.6.4: U V-D2 フィルター（図 6 ）を使用した場合, 多少等吸 収点をはずれたが，約 300 時間後キトールとなった。またV-V 2

（図 6）の場合もD2 の場合とほぼ同様な速度でキトールとなっ た（容器, 石英セル)。V-B2A（図6) を用いるとキトール化は するものの，その速度は非常におそく全部キトール化するには数
千時間を要するものと若えられた。V-03A（図6)では最初徐々 にキトール化が進むもののように見られたが，そののちまったく その吸収スペクトルに変化を与えなくなった。

\section{7 光線によるキトール化反応における $\beta$-カロチン添加の影}

淡色のビタミンA 油 $\left[E_{1 \mathrm{~cm}}^{1 \%}(327 \mathrm{~m} \mu)=19.1\right]$ に $\beta$-カロチン $0.08 \%$ および $0.16 \%$ 添加して日光照射し，そのキトール化する 速度を比較したところつぎのとおりであった。

$\begin{array}{cc}\text { 添加 } \beta \text {-カロチン }(\%) & \text { キトール化の日数 } \\ 0 & 9 \\ 0.08 & 18 \\ 0.18 & 23\end{array}$

\section{8 レチネンの日光照射とその生成物の分子蒸留}

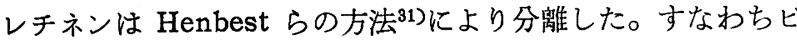
タミン $\mathrm{A}$ 浱縮物 $\left[E_{1 \mathrm{~cm}}^{1 \%}(324 \mathrm{~m} \mu)=834\right] 3 \mathrm{~g}$ を石油エーテル 30 cc に溶解し，活性二酸化マンガン ${ }^{32)} 20 \mathrm{~g}$ の塔を通し，これを $300 \mathrm{cc}$ の石油エーテルで洗い，この石油エーテル溶液から赤色の 粗レチネン $\left[E_{1 \mathrm{~cm}}^{1 \%}(378 \mathrm{~m} \mu)=675\right]$ ，を得た。これをクロマトグラ フにより精製したものは $383 \mathrm{~m} \mu$ に吸収極大 $\left(E_{1 \mathrm{~cm}}^{1 \%}=873\right)$ を示 した $(1.5 \mathrm{~g})$ 。このレチネンを椿油に溶解して日光照射した。そ の生成物は $293 \mathrm{~m} \mu$ 付近に吸収極大を示したが，これを分子蒸留 したところ，その吸収極大は長波長側に移った(図 7 )。

\section{9 アンヒドロビタミン $\mathbf{A} の$ 日光照射とその生成物の分子蒸} 留

ビタミン $\mathrm{A}$ 濃縮物 (1.8) $3 \mathrm{~g}$ を $1 / 30 \mathrm{~N}$ 塩化水素アルコール溶 液 $300 \mathrm{cc}$ に溶解し，15 分後，これに水を加え水酸化ナトリウム で中和，エーテルで抽出し，エーテル溶液を水洗，脱水し，これ からアンヒドロビタミン $\mathrm{A}$ を得た ${ }^{33)}$ 。これをさらに石油エーテル に溶解し，活性アルミナによって精製した。その吸収極大は 351 $\mathrm{m} \mu, 369 \mathrm{~m} \mu\left(E_{1 \mathrm{~cm}}^{1 \%}=1640\right), 381 \mathrm{~m} \mu$ に示したが, これを椿油に 溶解し日光照射した。その吸収スペクトルの変化は図 8 に示した が，またその生成物の分子蒸留を行なった。

\section{$1.10 \beta$-カロチンの日光照射}

試料とした $\beta$-カロチン油は結晶 $\beta$-カロチンを少量のクロロ ホルムに溶解し, 椿油を加え, 減圧下に溶郕を蒸留除去したもの であり，275，340，451，475 m $\mu\left(E_{1 \mathrm{~cm}}^{1 \%}\right.$ はそれぞれ 1.04, 0.97， $4.90 ， 4.13)$ に吸収極大を示した。この試料の日光照射による吸 収スペクトルの変化は図 9 に示した。

おわりに，本研究を行なうにあたり終始御指導，御教示をたま わった第 5 部長土屋知太郎博士，ならびに第 1 課長小林 正氏に 厚く感謝の意を表する。また試料を恵与された河合製薬株式会社 德田節夫氏に謝意を表する。な打紫外線照射実験, 退色試験機に 関し当所桑原仁太郎，鈴木 茂両氏の御援助を得た。

(1959 年 4 月, 日本化学会第 12 年会講演)

31) H. B. Henbest, E. R. H. Jones, T. C. Owen, J. Chem. Soc 1957, 4909.

32) J. Attenburrow, et al., ibid. 1952, 1094.

33) E. M. Shantz, J. D. Cawley, N. D. Embree, J. Am. Chem. Soc. 85, 901 (1943). 